PEMBELAJAR: Jurnal Ilmu Pendidikan, Keguruan, dan Pembelajaran

Volume 3 Nomor 1 April 2019

e-ISSN: 2549-9114 dan p-ISSN: 2549-9203

(Received: Januari 2019 ; Reviewed: Februari -2019; Published: April 2019)

DOI : https://doi.org/10.26858/pembelajar.v3i1.8719

\title{
Mengidentifikasi Model Pengembangan Instrumen Evaluasi Dalam E-Book Buku Teks Bahasa Indonesia
}

\author{
Imam Safi'i ${ }^{a}$, Prima Gusti Yanti ${ }^{\mathrm{b}}$, \\ ${ }^{a}$ Universitas Muhammadiyah Prof. DR. HAMKA \\ ${ }^{\mathrm{b}}$ Universitas Muhammadiyah Prof. DR. HAMKA \\ Corresponding e-mail: imamsafii2077@uhamka.ac.id
}

\begin{abstract}
Abstrak: Pemanfaatan e-book merupakan salah satu alternatif untuk menunjang efektivitas pembelajaran. Artikel ini menyajikan refleksi kritis atas pemanfaatan $e$-book bahasa Indonesia sebagai media pembelajaran dalam mengidentifikasi model pengembangan instrumen evaluasi yang terdapat dalam buku teks bahasa Indonesia. Kegiatan ini berkaitan dengan pengajaran mata kuliah Evaluasi Bahasa dan Sastra pada salah satu universitas swasta di Indonesia. Dalam pembelajaran ini, mahasiswa dibagi menjadi beberapa kelompok yang terdiri atas dua sampai dengan tiga orang untuk berkolaborasi dalam mengidentifikasi berbagai jenis alat evaluasi yang dikembangkan dengan pendekatan diskret, integrative, ataukah pragmatic. Setelah para mahasiswa mengidentifikasi berbagai jenis instrument evaluasi secara berkelompok, mereka kemudian mempresentasikan secara bergantian. Berbagai temuan yang telah dipresentasikan selanjutkan didiskusikan bersama-sama dan diberi penilaian. Hasil Pembelajaran menunjukkan, bahwa rata-rata nilai mahasiswa sangat tinggi, yaitu sebesar 82 . Pemanfaatan e-book bahasa Indonesia dapat dijadikan sebagai salah satu penunjang pembelajaran dalam mengidentifikasi model pengembangan instrument evaluasi pembelajaran bahasa Indonesia.
\end{abstract}

Kata kunci: pemanfaatan e-book, idetifikasi, pengembangan instrument evaluasi

\begin{abstract}
The use of e-books is one alternative to support the effectiveness of learning. This article presents a critical reflection on the use of Indonesian e-books as learning media in identifying models for the development of evaluation instruments contained in Indonesian textbooks. This activity is related to the teaching of Language and Literature Evaluation courses at one of the private universities in Indonesia. In this learning, students are divided into groups of two to three people to collaborate in identifying various types of evaluation tools developed with discrete, integrative, or pragmatic approaches. After the students identified various types of evaluation instruments in groups, they then presented them alternately. Various findings that have been presented later are discussed together and given an assessment. Learning Outcomes show that the average value of students is very high, which is equal to 82. The use of Indonesian e-books can be used as one of the supporting learning in identifying models for developing Indonesian learning learning evaluation instruments.
\end{abstract}

Keywords: utilization of e-books, identification, development of evaluation instruments 


\section{Pendahuluan}

Meningkatnya kehadiran e-book (buku elektronik) telah menjadi fokus utama di negaranegara di seluruh dunia. Di Amerika Serikat, ebook mewakili $28 \%$ dari total penjualan buku untuk tahun 2012. Di Jepang, konversi dari buku-buku kertas menjadi e-book diharapkan dapat dipercepat oleh penggunaan ponsel pintar dan PC tablet secara umum. (Tahara, Shimizu, Nakazawa, Nakamura, \& Yamagishi, 2018). Teknologi e-book berasal dari Project Gutenberg yang didirikan oleh Michael Hart pada tahun 1972, yaitu sebagai upaya untuk mendigitalkan publikasi serta mendistribusikannya secara luas, (Jin, 2014). Pembaca e-book sering juga disebut "E-book device" atau " 'E-reader". E-book adalah adalah perangkat elektronik khusus yang dirancang terutama untuk membaca buku dan majalah secara digital, (Burk, 2001).

Selanjutnya, bagaimana dengan prospek keberadaan e-book?. Menurut (Catenazzi, 1997; Shin, 2011; Shim, Kim, \& Altmann, 2016) akan menjadi ancaman serius bagi industri penerbitan cetak tradisional. Namun demikian, di sisi lain kemunculan e-book akan memberikan keuntungan, dapat meningkatkan kemahiran literasi, (Dore et al., 2018). Di Indonesia, saat ini e-book juga menjadi salah satu media pembelajaran yang sudah sangat populer. Menurut Sitepu (2011). Buku dalam tampilan elektronik (e-book) dapat terbit dan tersebar mendahului penerbitannya dalam wujud media cetak. Lebih jauh lagi, dengan berkembangnya penerbitan buku elektronik, definisi buku yang selama ini mengacu pada hasil cetak, perlu dikaji kembali dan disesuaikan sehingga mencakup buku elektronik. Osman dkk. mengatakan, bahwa buku elektronik, atau ebook dapat dijadikan oleh siswa, guru, dan sekolah sebagai media yang dapat mendukung atau meningkatkan proses pembelajaran. (Osman, Halim, \& Meerah, 2006). E-book saat ini menjadi salah satu bahan utama dalam kegiatan belajar. (Fojtik, 2015)

Keuntungan pemanfaatan e-book di atas sesuai dengan apa yang telah dipaparkan oleh Rusydi, bahwa e-book dapat memberikan beberapa keuntungan, yaitu 1) sangat menghemat ruang, 2) pengguna bisa mengakses file media digital kapan saja dan dimana saja, dan melalui perangkat apa saja, 3) Simpel dan mudah dibawa, ditransfer ke perangkat apapun, 4) cost dan harga jual yang lebih terjangkau, dan 5) menggalakkan gerakan ramah lingkungan. (Rusydi, 2014).

Sejalan dengan paparan di atas, maka artikel ini akan menyajikan tentang refleksi kritis atas pemanfataan e-book sebagai media pembelajaran Evaluasi Pengajaran Bahasa dan Sastra di salah satu perguruan tinggi di Indonesia. Adapaun yang akan dibahas dalam refleksi kritis ini adalah berkaitan dengan dua hal, yaitu 1) Bagaimanakah proses pembelajaran dengan pemanfaatan buku teks e-book dalam pembelajaran evaluasi pengajaran bahasa dan sastra? dan 2) Bagaimanakah efektivitas pemanfaatan buku teks e-book sebagai media pembelajaran evaluasi pengajaran bahasa dan sastra?

\section{Deskripsi E-book}

Önder (2010) mendefinisikan, bahwa ebook adalah sebagai bentuk digital dari beberapa atau semua buku cetak yang diproduksi sepenuhnya serta dirancang khusus dengan sistem digital dan dapat dilihat atau dibaca melalui perangkat portabel seperti komputer". Koleksi e-book atau buku elektronik juga dikenal dengan istilah buku digital adalah versi elektronik dari buku. Buku pada umumnya terdiri dari kumpulan kertas yang berisi teks dan gambar, e-book berisi informasi dalam bentuk digital dan juga dapat berwujud teks dan gambar. (Aan Prabowo, Heriyanto, 2013)

Menurut Wiji Suwarno (2011), e-book adalah versi elektronik dari buku. Jika buku pada umumnya terdiri dari kumpulan kertas 
yang berisi teks atau gambar, e-book berisi informasi digital yang juga dapat berwujud teks atau gambar. Sedangkan menurut Putut Laxman Pendit e-book adalah bentuk buku elektronik secara sederhana bias dilihat dalam bentuk teks yang tersaji dalam bentuk dokumen yang dibuat dengan wordprocessor, HTML, atau XML. Ebook (Aan Prabowo, Heriyanto, 2013). Yalman, (2014) menyatakan, bahwa e-book adalah kombinasi dari perangkat lunak dan perangkat keras yang memungkinkan teks untuk dirancang dalam lingkungan elektronik atau teks dalam format dokumen, txt dan pdf yang dapat dilihat dengan perangkat lain selain komputer (Morgan, 1999: 36; Cliff \& Dearnley 2003; Vidana 2003; Lam \& Ark., 2009; (Yalman, 2014)

Buku elektronik yang diimplementasikan pada tablet atau perangkat digital lainnya menyajikan sebuah kesempatan untuk membantu anak-anak belajar dari buku cerita dan membantu orang dewasa untuk beriteraksi secara efektif saat membacakan cerita untuk anak-anak. (Rvachew, Rees, Carolan, \& Nadig, 2017). Efektivitas pemanfaatan e-book ini juga diutarakan oleh (Glackin, Rodenhiser, \& Herzog, 2014) yang melakukan penelitian terhadap kinerja para mahasiswa keperawatan. Ia mengemukanan, bahwa dengan perangkat seluler dan e-book pekerjaan sosial mahasiswa keperawatan sangat meningkat. Banyak aspek positif dari pemanfaatan e-book dan teknologi seluler sebagai media pembelajaran.

Berdasarkan berbagai pendapat mengenai e-book di atas, maka dapat ditarik simpulan, bahwa yang dimaksudkan dengan e-book adalah buku yang disajikan melalui perangkat elektronik agar dapat dengan mudah diakses oleh pembaca di mana saja dengan biaya yang lebih hemat jika dibandingkan dengan buku cetak. Di samping itu, melalui e-book informasi juga dapat lebih cepat tersosialisasikan karena siswa atau mahasiswa dapat mengaksesnya dengan menggunakan smartphoe yang terkoneksi dengan internet.
Selanjutnya, berkenaan dengan hal tersebut artikel ini dimaksudkan untuk mendeskripsikan refleksi atas kegiatan pembelajaran yang menggunakan e-book sebagai media pembelajaran dalam mengidentifikasi model pengembangan instrument evaluasi pembelajaran yang terdapat dalam buku teks bahasa Indonesia. Dengan demikian, akan diperoleh data serta gambaran secara konkret apakah pemanfaatan e-book tersebut mampu menunjang efekktivitas pembelajaran ataukah tidak.

\section{Metode}

\subsection{Refleksi Pengajaran}

Pengajaran reflektif dipandang sebagai metode bagi para guru untuk memikirkan apa yang telah terjadi, mengapa itu terjadi, dan apa lagi yang bisa dilakukan untuk mencapai tujuan mereka. (Cruickhank dan Applegate, 1981; Solihati \& Mulyono, 2017). Melalui refleksi atas mereka

Praktik mengajar, guru dapat belajar tentang instruksi kelas mereka sendiri, siswa dan interaksi mereka selama pengajaran di kelas. Metode belajar mandiri ini memungkinkan guru untuk menghubungkan antara apa yang telah mereka pelajari dalam literatur dan itu praktik sebenarnya (Smith, 2012; Solihati \& Mulyono, 2017) Ketika merefleksikan pengajaran, para guru selain mempertimbangkan perspektif mereka sendiri, perspektif siswa dan, dalam pengertian yang lebih luas, perspektif orang tua, mereka juga perlu mempertimbangkan kelas konteks Farrell, 2007; Solihati \& Mulyono, 2017)

Dalam melakukan refleksi pembejalaran ini, kami melakukan kegiatan pembelajaran menganalisis beragam model pengembangan instrument evaluasi yang terdapat dalam buku teks e-book bahasa Indonesia. Dalam hal ini kami mengikuti prosedur yang telah dilakukan oleh Burhan-Horasanlı dan Prosedur Ortaçtepe. Pertama, kami merefleksikan pengalaman kami saat melakukan kegiatan belajar mengajar di 
lingkungan hybrid. Kedua, kami meninjau kami dokumen dan catatan pengajaran. Kemudian, kami mengevaluasi prosedur kelas, perannya teknologi dan sesi tatap muka serta pembelajaran kelas siswa kami dan interaksi.

\subsection{Partisipan}

Artikel ini berfokus pada refleksi praktik mengajar. Oleh karena itu, saya dan kolega mengambil peran sebagai instrument dalam melangsungkan pembelajaran dengan menggunakan media e-book. Selama kegiatan pembelajaran berlangsung, saya mengambil peran sebagai guru, sementara rekan saya sebagai kolaborator sekaligus pengamat kelas. Sebanyak dua puluh mahasiswa, yaitu laki-laki sebanyak lima dan perempuan sebanyak lima belas terlibat dalam proses pembelajaran mengidentifikasi jenis pengembangan istrumen evaluasi yang terdapat dalam e-book buku teks bahasa Indonesia.

Pengamatan kami sebelum penelitian ini menunjukkan bahwa dua puluh empat mahasiswa dapat mengoperasikan aplikasi komputer dasar, yang termasuk kemampuan mereka dalam pengolah kata, dan kemampuan mereka untuk membuat presentasi elektronik dan multi aplikasi media. Mahasiswa kami dapat mengoperasikan mesin pencari internet, melakukan korespondensi email, mengunggah dan mengunduh aplikasi dan file dari situs web serta melakukan pencetakan offline dan online. Selain komputer ini keterampilan, kami mengamati bahwa siswa kami dapat membuat hubungan antara mereka smartphone dan komputer atau laptop. Hal ini diperlukan karena dalam pembelajaran ini mahasiswa harus mengunduh e-book melalui internet, baik menggunakan smartphone maupun computer atau laptop. Setelah itu, pada saat evaluasi para mahasiswa juga harus mengundah soal kemudian mengejakan soal dan mengirimnya melalui email. Di samping itu, saat menjawab angket yang berisi sejumlah pernyataan mengenai pemanfaatan e-book mereka juga harus melakukannya secara online.

\subsection{Pengumpulan dan Analisis Data}

Data yang kami kumpulkan dalam kegiatan ini menggunakan dua metode yaitu pengamatan diri dan jurnal pembelajaran. Menurut Richards pengamatan diri memungkinkan guru untuk mengamati, mengevaluasi, dan mengelola perilaku mereka sendiri untuk mendapatkan pemahaman yang lebih baik tentang instruksinya kegiatan. (Solihati \& Mulyono, 2017). Dalam melakukan pengamatan diri ini, kami melakukan observasi mencatat dan menggunakan informasi yang dikumpulkan dari rencana pelajaran, dan umpan balik pada pekerjaan siswa. Selain pengamatan diri, jurnal siswa juga digunakan memfasilitasi refleksi kami. Kami meminta kepada para mahasiswa untuk memberikan tanggapan tentang pengalaman belajar mereka dengan menggunakan media e-book. Data yang dikumpulkan dari dua instrumen tersebut kemudian ditranskripsi dan dianalisis menggunakan analisis isi.

\section{Hasil dan Pembahasan}

3.1 Penggunaan e-book buku teks bahasa Indonesia dalam kegiatan pembelajaran Evaluasi Pengajaran Bahasa dan Sastra dapat membantu dosen dan mahasiswa dalam mengidentifikasi berbagai jenis pendekatan yang digunakan dalam pengembangan instrument evaluasi

\subsubsection{Mengidentifikasi jenis instrument evaluasi berpendekatan diskret}

Pada tahap ini kami mengawalinya dengan memberikan penjelasan mengenai pengertian pendekatan diskret dalam evaluasi pengajaran bahasa dan sastra. Tes diskret dibuat berdasarkan asumsi bahwa tes bahasa bisa dilakukan secara terpisah dalam beberapaa komponen bahasa. Komponen-komponen ini dapat dipisahkan menjadi dua kategori, yaitu komponen kompetensi berbahasa dan kompetensi kebahasaan. Komponen kompetensi berbahasa meliputi keterampilan menyimak, berbicara, membaca, dan menulis. Komponen 
kompetensi kebahasaan kompetensi kebahasaan mencakup mencakup pemahaman tentang fonologi, morfologi, leksikon, sintaksis, dan wacana, (Brown, 2003). Tes diskrit hanya menguji satu item bahasa, (Fulcher \& Davidson, 2007). Tes diskrit juga akan digunakan dalam pendekatan komunikatif sebagaimana diusulkan oleh Fulcher \& Davidson karena bisa jadi lebih efektif daripada tes integratif dalam kemampuan siswa. Jenis tes dikret juga akan lebih mudah untuk untuk melakukan penilaian daripada integrative. Sebagai contoh, tes yang dirancang untuk menilai ketepatan gramatikal. (Fulcher \& Davidson, 2007)

Setelah kami menjelaskan tentang karakteristik tes bahasa yang berpendekatan diskret tersebut, kami menugasi para mahasiswa secara berkelompok untuk mengidentifikasi berbagai alat evaluasi yang terdapat dalam ebook buku teks bahasa Indonesia yang telah diunduhnya melalui internet dengan menggunakan laptop atau smartphone. Mereka berusaha mengidentifikasi instrument evaluasi tesebut selama 40 menit. Setelah itu, tiap-tiap kelompok mempresentasikan temuannya secara bergantian, sekitar 5-10 menit dan dilanjutkan dengan diskusi dengan menerima komentar atau masukan dari kelompok lain. Melalui presentasi ini dapat diketahui, bahwa sebagian besar mahasiswa (kelompok) telah mampu mengidentifikasi dengan tepat mengenai jenis instrument berpendekatan diskret yang terdapat dalam buku teks e-book, namun msih terdapat dua kelompok yang belum mampu mengidentifikasi dengan tepat mengenai jenis instrument yang berpendekatan diskret yang terdapat dalam buku teks.

\subsubsection{Mengidentifikasi jenis instrument evaluasi berpendekatan integrative}

Oller (1979) sebagaimana dikutip oleh (Brown, 2003). mengemukakan, bahwa kompetensi bahasa adalah satu kesatuan yang tidak dapat diuji secara terpisah. Dalam tes integrative, aspek-aspek kebahasaan tidak dipisahkan satu dengan yang lain untuk diteskan secara secara sendiri, melainkan dalam wujud bahasa yang merupakan satu kesatuan. Tes kebahasaan yang integrative tidak secara khusus mengeteskan salah satu aspek atau keterampilan tertentu, melainkan sebuah tes dalam satu waktu meliputi beberpa aspek kebahasaan sekaligus. (Nurgiyantoro, 2001). Pendapat senada juga diutarakan oleh Djiwandono (2011) bahwa keterbatasan jangkauan tes diskret dalam penyelenggaraan pembelajaran bahasa memberikan peluang pada penerapan pendekatan integrative yang dalam banyak hal lebih sesuai dengan kebutuhan dan praktik penyelenggaraan tes bahasa. Lebih lanjut ia menekankan. bahwa integrative tidak hanya melibatkan dua atau tiga unsur bahasa, melainkan dapat juga berupa penggabungan dari lebih dari satu jenis kemampuan atau komponen bahasa.

Perkembangan lebih lanjut, keintegratifan pengajaran serta tes bahasa tidak hanya berkaitan dengan komponen bahasa meupun keterampilan berbahasa, melainkan berkaitan dengan aspek-aspek di luar bahasa yang secara bersamaan menunjang proses pengajaran dan kegiatan berbahasa. Sebagaimana diutarakan oleh (Wooten, 2008), bahwa bahasa, budaya, dan sastra diajarkan sebagai satu kesatuan yang berkelanjutan. Kami akan menunjukkan bagaimana linguistik fungsional sistemik (SFL) menawarkan teori bahasa dan pembelajaran yang menggabungkan antara isi pembicaraan dan budaya, (Huang \& Mohan, 2009). Dengan demikian, bahasa dianggap memiliki makna jika terintegrasi dengan konteks budaya. Anak-anak, misalnya, belajar bahasa dan menjadi sosialisasi ke dalam budaya rumah mereka melalui percakapan kehidupan sehari-hari. Bahasa belajar anak belajar tentang dunia, belajar bahasa dan budaya pada saat bersamaan.(Huang \& Mohan, 2009). Belajar bahasa adalah tentang mempelajari arti potensi bahasa dalam konteks budaya, (Teruya, 2009).

Mahasiswa yang mengikuti perkuliahan pada seksi ini sebanyak 22. Mereka dibagi 
menjadi enam kelompok untuk berkolaborasi dalam menganalisis instrument evaluasi pada buku teks ebook bahasa Indonesia yang berpendekatan diskret. Setelah diskusi kuranglebih selama 30 menit selanjutnya tiap-tiap kelompok diminta untuk presentasi secara bergantian. Beberapa hasil identifikasi yang telah dipresentasikan dapat diketahui, bahwa sebagian mahasiswa telah mampu mengeidentifikasi dengan tepat, namun masih terdapat beberapa yang masih salah dalam mengidentifikasi.

Berdasarkan keberagaman kemampuan mahasiswa dalam mengidentifikasi jenis pendekatan yang digunakan dalam pengembangan instrument pada buku teks atau ebook kemudian kami memberikan penjelasan ulang mengenai karakteristik instrument evaluasi bahasa Indonesia yang berpendekatan integratif. Dengan demikian, akhirnya diperoleh pemahaman yang sama mengenai pemehaman tentang pengembangan alat evaluasi bahasa Indonseia dengan menggunakan pendekatan diskret.

\subsubsection{Mengidentifikasi jenis instrument evaluasi berpendekatan pragmatik}

Pragmatik digambarkan sebagai studi tentang penggunaan bahasa, khususnya fokus tentang bagaimana orang memanfaatkan konteks dalam pemahaman dan ekspresi, dan bagaimana faktor-faktor kontekstual berinteraksi dengan makna linguistik. (Loukusa, Mäkinen, Kuusikko-Gauffin, Ebeling, \& Leinonen, 2018) Pragmatik mengacu pada penggunaan dan pemahaman seseorang atas bahasa verbal dan nonverbal yang tepat, dalam konteks komunikasi di mana itu terjadi, (Smith, Næss, \& Jarrold, 2017) Kemampuan pragmatik memengaruhi cara seseorang berkomunikasi dan berperilaku dalam situasi sosial, yang pada gilirannya memengaruhi cara yang lain menanggapi orang tersebut, yang kemudian mempengaruhi tindakannya. (Loukusa et al., 2018)
Mengacu pada batasan tentang pembelajaran bahasa dengan pendekatan pragmati di atas, kemudian para mahasiswa melakukan identifikasi berbagai instrument evaluasi yang terdapat dalam e-book buku teks bahasa Indonesia yang berpendekatan pragmatic. Kegiatan tersebut kami langsungkan selama 40 menit. Setelah itu, para mahasiswa secara bergantian mempresentasikan hasil identifikasinya dan para mahasiswa yang lain memberikan tanggapan terhadap hasil identifikasi yang telah dipresentasikan.

\subsection{Penggunaan e-book buku teks bahasa Indonesia dapat dijadikan sebagai alternative penugasan dalam mengidentifikasi berbagai pendekatan dalam pengembangan intrumen evaluasi pengajaran bahasa}

E-book bukanlah satu-satunya bahan ajar yang dapat digunakan sebagai media pembelajaran. Namun demikian, berkaitan dengan perkembangan teknologi yang begitu pesat pemanfaatan e-book bisa dijadikan sebagai salah satu alternative yang sangat menarik untuk dijadikan sebagai media dalam melagsungkan pembelajaran. Hal ini dikarenakan para mahasiswa sudah bergitu akrab dengan teknologi. Dengan demikian, pembelajaran Evaluasi Pengajaran Bahasa dan Sastra yang memanfaatkan media e-book bisa dinyatakan sebagai salah satu teknik pembelajaran yang berusaha menyesuaikan dengan situasai keseharian para mahasiswa yang begitu akrab dengan gawai.

\subsection{Penggunaan e-book buku teks bahasa Indonesia dapat memfasilitasi penugasan belajar dan umpan balik}

Kemandirian cara belajar adalah bagian dari tujuan pembelajaran. E-book dapat dijadikan sebagai salah upaya untuk mewujudkan hal tersebut. Melalui selancar dunia maya, mahasiswa selain mendapatkan 
hiburan juga dapat belajar secara efektif dengan memanfaatkan e-book. Berbagai bentuk penugasan dapat dilakukan dengan memanfaatkan media e-book tersebut. Mahasiswa tidak akan terkendala dengan masalah tempat dan waktu karena mereka bisa melakukan aktivitas belajar di manapun dan kapanpun.

Efektivitas pemanfaatan e-book ini dapat kami peroleh berdasarkan hasil tes serta hasil survey secara online yang diberikan kepada para mahasiswa. Hasil tes kami lakukan untuk mengetahui tingkat pemahaman para mahasiswa tentang model pengembangan intrumen yang berpendekatan diskret, integrative, dan pragmatic yang terdapat pada e-book buku teks bahasa Indonesia. Tes yang kami berikan adalah berupa instruksi kepada para mahasiswa untuk mengembangkan mengidentifikasi dan mengembangkan beberapa intrumen evaluasi pengajaran bahasa dan sastra dengan mengacu pada berbagai pendekatan pengajaran serta tes bahasa yang telah dibahas sebelumnya.

Berdasarkan tes yang telah dilakukan dapat diketahjui, bahwa rata-rata para mahasiswa telah memahami jeni-jenis pengembangan alat evaluasi bahasa dan sastra yang berpendekatan diskret, integrative, dan pragmatic dengan baik. Rata-rata hasil tes siswa mencapai 82.

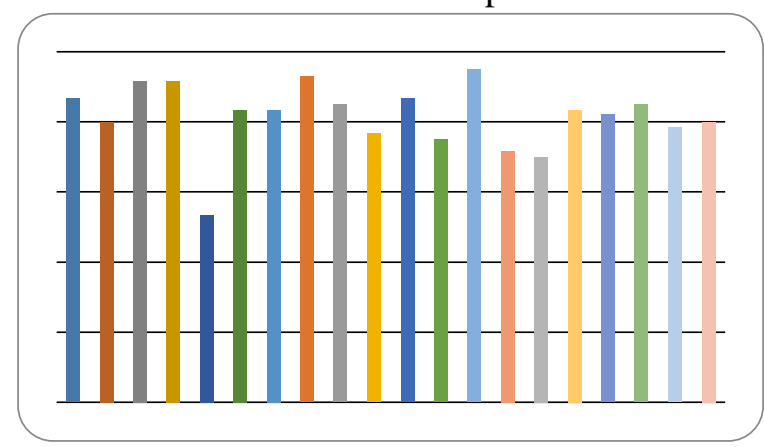

Gambar 1: Grafik Hasil Belajar Mahasiswa

Berdasarkan data pada tabel di atas dapat diketahui, bahwa hasil tes pemahaman para mahasiswa terhadap pengemabangan intrumen evaluasi dalam buku teks e-book bahasa Indonesia sangat memuasakan. Hal ini menunjukkan, bahwa pemanfaatan e-book memilki efektivitas yang cukup tinggi dalam menunjang pembelajaran, yaitu sebagaimana temuan Liesaputra dan Witten, bahwa melalui pemanfaatan e-book, pembelajar mampu menyelesaikan tugas lebih efisien tanpa kehilangan tingkat ketepatan atau akurasi dalam memamahami suatu suatu hal.Di samping itu, pembelajara juga lebih menyukai pemanfaatan e-book daripada buku cetak. (Liesaputra \& Witten, 2012). Demikian halnya dengan temuan Gueval dkk., secara kuantitatif kemahiran dan kepuasan para siswa atas pemanfaatan terus meningkat dari waktu ke waktu. Kedua kelompok menyatakan perasaan netral mengenai e-book yang meningkatkan pembelajaran. (Gueval, Tarnow, \& Kumm, 2015).

Selanjutnya, menurut Roskos dkk., bahwa e-book dapat digunakan sebagai sumber daya kurikulum keaksaraan dan kolaborasi yang lebih aktif di antara penerbit, pengembang IT dan pendidik untuk meningkatkan kualitas platform e-book. (Roskos, Brueck, \& Lenhart, 2017). Pemanfaatan e-book juga akan membantu pustakawan untuk meningkatkan pekerjaan dan membuat upaya pengembangan dan pengumpulan informasi yang lebih baik di sebuah institusi. (Hanz \& McKinnon, 2018).

Selanjutnya, berdasarkan hasil survey mengenai tanggapan para mahasiswa atas pemanfataan e-boook buku teks bahasa Indonesia sebagai media pembelajaran evaluasi pengajaran bahasa dan sastra juga menunjukkan, bahwa rata-rata para mahasiswa merasa puas. Hal ini sebagaimana terlihat dalam grafik berikut.

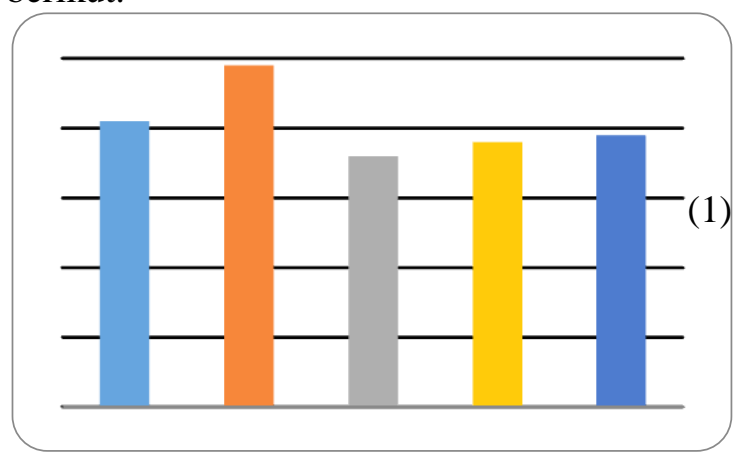


Gambar 2: Grafik Hasil Survei Tanggapan Mahasiswa

\section{Keterangan :}

1. Kemudahan mengakses e-book

2. Kehematan e-book

3. Keefektifan e-book

4. Kepraktisan e-book

5. Kepemahaman atas pemenfaatan e-book

Kepuasan para mahasiswa berkenaan dengan pemanfanfaatan e-book tersebut juga sejalan dengan beberapa penelitian yang dilakukan sebelumnya, yaitu menurut Letchumanan dan Tarmizi. Di antara alasan yang diberikan untuk menggunakan e-book adalah "tersedia sepanjang waktu", "dapat dicari" dan "memungkinkan navigasi yang mudah". Sebaliknya, mereka yang belum pernah menggunakan e-book menyatakan bahwa mereka tidak akrab dengan teknologi. Hasilnya menunjukkan bahwa mayoritas responden suka menggunakan e-book untuk mencari bahan untuk tugas mereka. (Letchumanan \& Tarmizi, 2010). Di samping itu, berdasarkan penelitian yang telah dilakukan oleh (Fu, Zhang, \& Yan, 2018) yang berkaitan dengan sikap para penerbit mengenai menjamurnya e-book menunjukkan, bahwa terdapat peningkatan permintaan e-book oleh perpustakaan akademik guna mempromosikan proses transformasi digital penerbit akademik.

\section{KESIMPULAN}

Berdasarkan penelitian yang telah kami dilakukan dapat disimpulkan, bahwa pemanfanfaatan e-book sebagai salah satu sumber belajar dapat meningkatkan hasil belajar mahasiswa dalam memahahami dan mengembangkan instrument evaluasi pengajaran bahasa dan sastra Indonesia. Di samping itu, para mahasiswa juga merasa cukup puas atas pemanfaatan e-book sebagai salah satu media pembelajaran. Menurut para mahasiswa, e-book sangat mudah diakses, hemat, efektif, dan prakktis sehingga dapat meningkatkan tingkat pemahaman dalam proses pembelajaran evaluasi pengajaran bahasa dan sastra Indonesia.

Kami pun menyadari sepenuhnya mengenai beberapa kelemahan dalam penelitian ini. Penelitian ini merupakan studi reflektif atas pembelajaran yang kami langsungkan selama setengah semester dalam mata kuliah Evaluasi Pengajaran Bahasa dan Sastra di salah satu peguruan tinggi swasta di Idonesia. Oleh karena itu, hasilnya pun tidak dapat digeneralkan yang berlaku umum pada tempat dan waktu yang berlainan. Namun demikian, hasil penelitian ini tetap dapat dijadikan sebagai salah rujukan untuk menambah informasi yang berkaitan dengan pemanfaatan e-book.

\section{DAFTAR PUSTAKA}

Aan Prabowo, Heriyanto, S.Sos., M. I. (2013). Analisis Pemanfaatan Buku Elektronik (EBook) Oleh Pemustaka di Perpustakaan SMA Negeri 1 Semarang. Jurnal Ilmu Perpustakaan, 2(2), 1-9. Retrieved from http://ejournals1.undip.ac.id/index.php/jip\%5CnANALIS IS

Brown, H. D. (2003). Language Assessment Principles and Classroom Practices. -, 336. https://doi.org/10.1017/CBO97811074153 24.004

Dore, R. A., Hassinger-Das, B., Brezack, N., Valladares, T. L., Paller, A., Vu, L., ... Hirsh-Pasek, K. (2018). The parent advantage in fostering children's e-book comprehension. Early Childhood Research Quarterly, 44, 24-33. https://doi.org/10.1016/j.ecresq.2018.02.00 2

Fojtik, R. (2015). Ebooks and Mobile Devices in Education. Procedia - Social and Behavioral Sciences, 182, 742-745. https://doi.org/10.1016/j.sbspro.2015.04.82 4 
Fu, W. Q., Zhang, M., \& Yan, L. Y. (2018). Academic e-Book Publishing in China: An Investigation of Current Status and Publishers' Attitudes. Journal of Academic Librarianship, 44(1), 15-24. https://doi.org/10.1016/j.acalib.2017.12.00 8

Fulcher, G., \& Davidson, F. (n.d.). LANGUAGE TESTING.

Glackin, B. C., Rodenhiser, R. W., \& Herzog, B. (2014). A Library and the Disciplines: A Collaborative Project Assessing the Impact of eBooks and Mobile Devices on Student Learning. Journal of Academic Librarianship, 40(3-4), 299-306. https://doi.org/10.1016/j.acalib.2014.04.00 7

Gueval, J., Tarnow, K., \& Kumm, S. (2015). Implementing e-books: Faculty and student experiences. Teaching and Learning in Nursing, 10(4), 181-185. https://doi.org/10.1016/j.teln.2015.06.003

Hanz, K., \& McKinnon, D. (2018). When Librarians Hit the Books: Uses of and Attitudes Toward E-Books. Journal of Academic Librarianship, 44(1), 1-14. https://doi.org/10.1016/j.acalib.2017.12.01 8

Huang, J., \& Mohan, B. (2009). A functional approach to integrated assessment of teacher support and student discourse development in an elementary Chinese program. Linguistics and Education, 20(1), $22-38$.

https://doi.org/10.1016/j.linged.2009.01.00 6

Jin, C. H. (2014). Adoption of e-book among college students: The perspective of an integrated TAM. Computers in Human Behavior, 41, 471-477. https://doi.org/10.1016/j.chb.2014.09.056

Letchumanan, M., \& Tarmizi, R. A. (2010). Utilization of e-book among university mathematics students. Procedia - Social and Behavioral Sciences, 8, 580-587. https://doi.org/10.1016/j.sbspro.2010.12.08 0

Liesaputra, V., \& Witten, I. H. (2012). Realistic electronic books. International Journal of Human Computer Studies, 70(9), 588-610. https://doi.org/10.1016/j.ijhcs.2012.02.003

Loukusa, S., Mäkinen, L., Kuusikko-Gauffin, S., Ebeling, H., \& Leinonen, E. (2018). Assessing social-pragmatic inferencing skills in children with autism spectrum disorder. Journal of Communication Disorders, (December 2017). https://doi.org/10.1016/j.jcomdis.2018.01.0 06

Muhammad, M., Rahadian, D., \& Safitri, E. R. (2017). Penggunaan Digital Book Berbasis Android Untuk Meningkatkan Motivasi Dan Keterampilan Membaca Pada Pelajaran Bahasa Arab. Pedagogia Ilmu Pendidikan, 15(2), 690-701. Retrieved from

http://ejournal.upi.edu/index.php/pedagogi a/article/view/8094

Osman, K., Halim, L., \& Meerah, S. M. (2006). What Malaysian science teachers need to improve their science instruction: A comparison across gender, school location and area of specialization. Eurasia Journal of Mathematics, Science and Technology Education, 2(2), 58-81. https://doi.org/10.1016/j.sbspro.2012.06.90 3

Roskos, K., Brueck, J., \& Lenhart, L. (2017). An analysis of e-book learning platforms: Affordances, architecture, functionality and analytics. International Journal of Child-Computer Interaction, 12, 37-45. https://doi.org/10.1016/j.ijcci.2017.01.003

Rusydi, I. (2014). Pemanfaatan E-Journal Sebagai Media Informasi Digital Ibnu Rusydi. Iqra', 8(2), 200-210. 
Rvachew, S., Rees, K., Carolan, E., \& Nadig, A. (2017). Improving emergent literacy with school-based shared reading: Paper versus ebooks. International Journal of ChildComputer Interaction, 12, 24-29. https://doi.org/10.1016/j.ijcci.2017.01.002

Shim, D., Kim, J. G., \& Altmann, J. (2016). Identifying key drivers and bottlenecks in the adoption of E-book readers in Korea. Telematics and Informatics, 33(3), 860871.

https://doi.org/10.1016/j.tele.2015.12.009

Smith, E., Næss, K. A. B., \& Jarrold, C. (2017). Assessing pragmatic communication in children with Down syndrome. Journal of Communication Disorders, 68 (December 2015), $10-23$. https://doi.org/10.1016/j.jcomdis.2017.06.0 03

Solihati, N., \& Mulyono, H. (2017). A hybrid classroom instruction in Second Language Teacher Education (SLTE): A critical reflection of teacher educators. International Journal of Emerging Technologies in Learning, 12(5), 169-180. https://doi.org/10.3991/ijet.v12i05.6989

Tahara, K., Shimizu, H., Nakazawa, K., Nakamura, H., \& Yamagishi, K. (2018). Life-cycle greenhouse gas emissions of ebooks vs. paper books: A Japanese case study. Journal of Cleaner Production, 189, 59-66.

https://doi.org/10.1016/j.jclepro.2018.03.3 21

Teruya, K. (2009). Grammar as a gateway into discourse: A systemic functional approach to Subject, Theme, and logic. Linguistics and Education, 20(1), 67-79. https://doi.org/10.1016/j.linged.2009.01.00 8
Wooten, J. (2008). Turning point: Toward an integrative model of foreign language education. Linguistics and Education, 19(1), 79-81. https://doi.org/10.1016/j.linged.2007.11.00 5

Yalman, M. (2014). Preservice teachers' views about E-book and their levels of use of Ebooks. Turkish Online Journal of Educational Technology, 13(2), 138-147. https://doi.org/10.1016/j.sbspro.2015.01.46 9 